IRSH 6I (2016), Special Issue, pp. I65-i 85 doi: I0.10I7/S00208590I6000390 (C) 2016 Internationaal Instituut voor Sociale Geschiedenis

\title{
The Labour Recruitment of Local Inhabitants as Rōmusha in Japanese-Occupied South East Asia*
}

\author{
TAKUMA MELBER \\ Karl Jaspers Centre for Advanced Transcultural Studies \\ Voßstraße 2, Building 4400, 69I Is Heidelberg, Germany \\ E-mail: takuma_@gmx.de
}

\begin{abstract}
During World War II, Japan, as occupying power, mobilized thousands of labourers in South East Asia. While the history of Allied prisoners of war (POWs) deployed as forced labourers on the Burma-Siam "Death Railway" is well known, the coercive labour recruitment of local inhabitants as so-called rōmusha has, until today, remained an almost completely untold story. This article introduces rōmusha, with a particular focus on the Burma-Siam Railway, and presents the methods used by the occupying powers to recruit local inhabitants in Java, Malaya, and Singapore, initially as volunteers, and increasingly using force. We look, too, at the tactics and strategies of avoidance the locals were able to deploy. The article offers insights into the poor working conditions on the railway, discusses the body count, and gives an idea of the huge impact of the forced labour recruitment not only in economic terms, but also in terms of the effect it had on the social structure at both the micro and macro levels.
\end{abstract}

\section{INTRODUCTION}

When seen in the context of the whole of human history, it is obvious that the four and a half years of the Japanese occupation of South East Asia between I 942 and summer 1945 were a short period. Prior to this, Japan, as the new imperialist player in Asia, had annexed an area of North East Asia (Korea, Taiwan, and Chinese territories) larger than itself. For decades, historians have been debating whether or not and to what extent the Japanese empire through its imperialism caused postwar changes in South East Asian societies, although it is beyond question that World War II was a decisive turning point in the region's history, for until the outbreak of war almost all South East Asian countries had been ruled by Western colonial empires. However, before the independent nation states in South East Asia emerged after World War II, the empire of Japan conquered the region and controlled it during the war years. The war, conducted as a "total war", had a

\footnotetext{
* Personal names of Japanese individuals are given according to the Japanese style of family name followed by given name.
} 
huge social impact and deeply affected labour relations not only in Japan itself, but also in the occupied South East Asian countries, as especially during the second part of the occupation Japan felt compelled to mobilize labour on a large scale. The first months of the Pacific War, which began with the surprise attack on Pearl Harbor, proved to be very successful for Japan's army and navy, and the fall of Singapore on is February 1942 and the attendant surrender of British forces there was the climax of the Japanese invasion of the Malay Peninsula. As part of their Burma Campaign, Japanese troops captured Rangoon on 8 March 1942 and very quickly occupied all the islands of the Dutch East Indies. However, the naval Battle of Midway at the beginning of June $194^{2}$ proved to be the turning point of the war, as it marked the moment that Japan gradually began to lose control of the Pacific.

Japan's war leaders saw that the military situation in the Asia-Pacific theatre was steadily deteriorating, along with the food supply, which was now going from bad to worse. The Japanese empire and its South East Asian possessions were economically isolated from international trade, and Japan's economic situation worsened from the middle of I942. The military administration adopted drastic measures in their attempts to solve the problem of shortages of food and essential goods, as well as to guarantee the production of war materials to strengthen the domestic economy of the so-called Greater East Asia Co-Prosperity Sphere (Daitōakyōeiken). Further, the aim of Japan's leadership was to continue to wage war and, of course, to maintain wartime logistics, such as the movement of raw materials essential for the war effort. In addition, because of Japan's steadily worsening military situation fortifications were constructed in the occupied zone in preparation for an Allied invasion. ${ }^{I}$ With the aim of improving productivity as well as to exploit available manpower for military and economic needs, Japan increasingly conducted "total mobilization" of its society, right up to the end of the war. For example, Japanese women were set to work in factories, replacing men who were then conscripted to the battlefronts in the Asia-Pacific region. ${ }^{2}$ In contrast to Western countries at war - especially Great Britain, where, from an early stage, the mobilization of women had been conducted highly systemically and on a large scale - Japan began to

I. Paul H. Kratoska, Nihon senryōka ni okeru tōnanajia no keizai jōkyō [The Economic Conditions in Japanese-Occupied South East Asia], in Kyeungdal Chō et al. (eds), Higashiajia kingendai tsūshi [East Asian Contemporary History], vol. 6: Ajia taiheiyō sensō to "daitōakyōeiken", 1935-1945 [The Asia-Pacific War and the "Greater East Asia Co-Prosperity Sphere”, 1935-1945] (Tokyo, 20I I), pp. 260-280, 269f.; Shigeru Satō, "Rōmusha”, in Peter Post (ed.), The Encyclopedia of Indonesia in the Pacific War (Leiden, 2010), pp. 197-201, 197.

2. For the role of women in Japan's war economy, see Thomas R. Havens, "Women and War in Japan, I937-45”, American Historical Review, 80:4 (1975), pp. 91 3-934, 91 3ff.; Regine Mathias, "Women and the War Economy in Japan", in Erich Pauer (ed.), Japan's War Economy (London, I999), pp. 65-8 I, 66ff. 
enlist women as labourers for the war economy comparatively late. The conscription of female labourers in Japan did not begin before 1943 and was intensified only from I 944 onwards, when deteriorating war conditions and the shortage of labour had made it unavoidable, rather a last resort. But diverse objections prevailed against female labourers in wartime Japan generally. From the state's point of view, the Japanese woman should not play a role as a productive human resource, for her role was motherhood, its value being in the production literally of manpower.

But the consequences of the war were not limited to the Japanese homeland. The impact of the war as well as the influence of Japan as the occupying power was huge on labour relations in the occupied territories too. Generally speaking, from 1942 to I 945 the whole economy of South East Asia was subordinated to the principal aim of the imperialist state, which was to win the war at all costs. Initially, the Japanese empire had planned to build an Asian economic bloc, under Japanese leadership, of course. The occupied North East Asian territories were to be developed as a centre of industrial production, while South East Asia was to function as a base for the supply of raw materials and as a market for industrial goods. ${ }^{3}$ Japan's short-term plan intended to cut off its enemies from South East Asia's natural resources - vital for strategic purposes - as well as to secure and exploit them for itself.

However, Japan's industry had to align itself to the war effort and US submarines kept up a solid campaign against Japanese cargo ships. For that reason, the Japanese empire was unable to establish a real exchange of South East Asian raw materials for the production of goods in Japan, on the one hand, and of consumer goods from Japan for sale in South East Asia, on the other. So what had originally been planned as a relationship - however naturally unequal - of exchange became in the main one-way traffic along a road of exploitation. ${ }^{4}$ The occupying power looked on South East Asia purely as a source of war resources - meaning not only raw materials such as petroleum, rubber, tin, bauxite, or lumber, but also the "human resource" of the local inhabitants.

Accordingly, following its aim to exploit South East Asia's resources to the greatest degree, Japan's armed forces tried to systematize one quite specific kind of labour by mobilizing forced labour. Forced labour existed alongside other types of labour, such as contract work or normal wage labour, but was considered indispensable by Japan's authorities owing to economic necessity and for strategic military reasons. The outcome of the

3. Shigeru Satō, "Relocation of Labor and the Rōmusha Issue", in Post, The Encyclopedia of Indonesia in the Pacific War, pp. 245-260, 253.

4. Norman G. Owen, "Economic and Social Change", in Nicholas Tarling (ed.), The Cambridge History of Southeast Asia, Volume Two: The Nineteenth and Twentieth Centuries (Cambridge [etc.], I992), pp. 467-527, 469 . 
Battle of Midway led Tokyo to decide to transform conditions in South East Asia, especially in the last two years of Japanese occupation, and one of the changes was the forced recruitment of romusha, ${ }^{5}$ in other words, the local inhabitants of the South East Asian territories. The prime function of the rommusha would be to do manual labour.

This article, then, will focus first on the recruitment by the Japanese of the local inhabitants of South East Asia, particularly Malaya and Singapore, for forced labour, but will also explain how some locals were able to avoid recruitment. The continued general lack of data makes research on rommusha rather difficult: "the exact scale of mobilization [of labour] for military and civilian purposes cannot be ascertained, as the official statistics are incomplete and also because there was much unofficial mobilization by both the military and the Military Administration". "However, by looking at the forced deployment of indigenous workers from Malaya, Singapore, and Java for manual labour, this article presents a very important part of the mobilization of forced labour during the Japanese occupation of South East Asia in general, and forms an addendum to the much better researched fate of Allied POWs as forced labourers. And we shall see how the case of the romusha is a simultaneous example of how Japan shaped labour during the war for its own imperialist ends.

5. Satō defined the term "rōmusha" as follows: "rōmusha is a Japanese word meaning an unskilled laborer who carries out temporary construction work. Such a laborer typically is a single male, lives in laborers' quarters as long as his employment lasts, and moves on when it ends, looking for another job". Satō, "Rōmusha", p. 197. In her classic work on the history of rōmusha, Kurasawa underlined the fact that in Indonesia the term "rōmusha" does not mean just "labourer". Rōmusha were "persons who were recruited by force during the Japanese occupation period to do hard physical work". Aiko Kurasawa, Nihon senryōka no Jawa nōson no benyō [Transformation in the Rural Areas of Japanese-Occupied Java] (Tokyo, I992), p. I80. In the pre-occupation period, the term "coolie" (Dutch koelie) was commonly used for day labourers or contract workers. The Chinese transcription of “coolie” (苦力) included the characters 苦 $(k \bar{u})$, which can be translated as "suffering”, “pain”, or "sorrow”, and 力 (li), for (physical) strength or labour. Because of this quite negative connotation, the Japanese occupying force introduced the term "romusha (労務者)", using the characters 労 $(r \bar{o})$ to mean “work”, "labour”, 務 $(m u)$ meaning “duty”, "service", and者 (sha) meaning "person". Shigeru Satō, War, Nationalism and Peasants: Java under the Japanese Occupation, 1942-1945 (Armonk, NY, 1994), p. I54, fn. I. According to Lieutenant Colonel Sugiyama, it was forbidden for Japanese soldiers on the Burma-Siam Railway to use the term "coolie". One alternative to "rōmusha" was the neutral term “kōin" (工員), meaning a factory worker. But the use of the term "kōin" caused problems on the Burmese side: "But, since the [Japanese] soldiers who come from the north of the Kanto district pronounce ' $\mathrm{l}$ ' as 'e', 'Koin' became 'Koen'. This word 'Koen' is somewhat similar to Burmese 'KOE', 'dog', which at times gave rise to their [Burmese forced labourers'] feelings of animosity towards us." In Paul H. Kratoska (ed.), The Thailand-Burma Railway, 1942-1946: Documents and Selected Writings, vol. 4 (London, 2006), p. 7 I.

6. Satō, "Relocation of Labor", p. 25 I. 


\section{FORCED LABOUR DURING THE JAPANESE OCCUPATION}

By February 1942, the Japanese investigation committee for the inspection of all southern territories had already created the expectation in Singapore that Java should become the key source of "human labour", presumably because of its relatively large population and its convenient central location in South East Asia. On Io July I942, the Japanese army and navy together arranged the transport of rommusha from Java, which was under the administration of the Japanese army, to territories controlled by the Japanese navy. At a later conference, the directors responsible for rōmusha affairs within the Southern Army declared Java a key source for the supply of romusha. Finally, in September I944, the provisional House of Councillors in Tokyo ordered an increase in their supply. ${ }^{7}$

Forced labour on the Burma-Siam Railway (Taimentetsudō) has remained the most famous example of its use in Japanese-occupied South East Asia. Construction of the 4Is-kilometre-long railway connection between Ban Pong in Siam and Thanbyuzayat in the south-east of Burma began in July 1942. The Japanese occupying power hoped to utilize the Burma-Siam Railway both to avoid having to transport supplies by dangerous sea routes from its South East Asian territories to the front in Burma, and ultimately to link Bangkok in Siam and Rangoon in Burma. ${ }^{8}$

In spring 1943, the Japanese 29th Army was required to supply contingents of labourers for the Burma-Siam Railway. ${ }^{9}$ Apart from 92,000 Burmese rōmusha, 78,204 forced labourers from Malaya, mainly indigenous Malays and Tamils, made up the second largest group on the "Death Railway". Seventy thousand of those 78,204 Malayan romusha were recruited and sent to the railway between April and September 1943, and approximately 4I per cent of those 70,000 died as a consequence. ${ }^{\text {IO }}$

It must be mentioned that systematic large-scale recruitment of rōmusha on Java began only after completion of the Burma-Siam Railway, which was built between July 1942 and October $1943 .{ }^{\text {II }}$ As is still the case today,

7. For the decisions concerning the labour mobilization see Kenichi Gotō, Nibon senryōki indoneshia kenky $\bar{u}$ [Research on the Japanese Occupation Period in Indonesia] (Tokyo, I989), p. 99, and Satō, War, Nationalism and Peasants, p. I 56.

8. Toshiharu Yoshikawa, "Taimentetsudō" [The Burma-Siam Railway], in Chō et al., Higashiajia kingendai tsüshi, p. 42 f.

9. Michiko Nakahara, "Nihon senryōki eiryōmaraya ni okeru rōmushadōin - taimentetsudō no bāi" [The Mobilization of Rōmusha in Japanese-Occupied British Malaya: The Case of the Burma-Siam Railway], in Aiko Kurasawa (ed.), Tōnanajiashi no naka no nibon senryō [The Japanese Occupation in South East Asian History] (Tokyo, 200I), pp. I7I-I98, I78.

Io. The National Archives of the UK, Public Record Office, London [hereafter, PRO], WO 203-5823, SEATIC Bulletin No. 246: Burma-Siam Railway, 8 October 1946.

I I. Satō, War, Nationalism and Peasants, p. I 5 . 
seventy per cent of the population of Indonesia (seventy million people) lived on Java, ${ }^{\mathrm{I}}$ hence Java becoming the primary source of forced labourers during the Japanese occupation. It is, therefore, no surprise that the research community tends to use the generic term romusha more or less as a synonym for forced labourers from Java.

In total, between 200,000 and 300,000 forced labourers were sent from Java to other territories in Japanese-occupied South East Asia - 31,000 of them to Malaya alone. ${ }^{\mathrm{I}}$ The majority, more than forty per cent, of those Javanese romusha sent overseas arrived on the island of Sumatra, which lies between the Malay Peninsula and Java. During the first year of the Japanese occupation from 28 March 1942 to April 1943, Sumatra was a single administrative and political unit with Malaya. ${ }^{\mathrm{I}}$ According to a Dutch intelligence report, a total of about $\mathrm{r} 20,000$ Javanese and Chinese rōmusha were transported from Java to Sumatra during the Japanese occupation. ${ }^{\text {Is }}$

Japanese primary sources reveal that the Japanese 29th Army in Malaya requested 5 5,477 forced labourers from Java between April 1944 and March 1945. Their request was granted by Southern Army Headquarters in Singapore, which sent 22, 100 rōmusha from Java to the Malay Peninsula. ${ }^{16}$ It seems that, faced with dwindling powers, the occupying force could manage only a limited exploitation of that source of rōmusha.

\section{METHODS OF RECRUITMENT}

The Southern Army and the Japanese military administration in Malaya (Mare Gunseikanbu) demanded the recruitment of I00,000 labourers to be

I 2. Idem, "Relocation of Labor", p. 245 .

I 3. Kurasawa, Nihon senryōka no Jawa nōson no henyō, p. I8off.; Remco Raben, "Indonesian Rōmusha and Coolies under Naval Administration: The Eastern Archipelago, 1942-45", in Paul H. Kratoska (ed.), Asian Labor in the Wartime Japanese Empire: Unknown Histories (Armonk, NY, 2005), pp. 197-2 I2, I97; Satō, War, Nationalism and Peasants, p. I $58 f$. Besides the 300,000 Javanese forced labourers who were sent abroad, many Javanese, too, were impressed for forced labour on Java. Kratoska, Nihon senryōka ni okeru tōnanajia no keizai jōkyō, p. 269. Examples for railway construction work, shipbuilding, and mining can be found in Satō, War, Nationalism and Peasants, p. I79ff.

I4. Satō, "Rōmusha", p. 201.

I 5. NIOD Instituut voor oorlogs-, holocaust- en genocidestudies, Indische Collectie, Amsterdam [hereafter, NIOD], Netherlands Forces Intelligence Service (NEFIS), Dept. I - Section II (Economic Technical Department): Report concerning data in the hands of the above-mentioned Section of NEFIS concerning the number of romusha's outside Java, March 1946.

16. The notes of Mori Fumio (Mori Fumio, Gunsei Shubo = 森文雄、軍政手簿) are available in the Bōeikenkyūjo (防衛研究所), The National Institute for Defence Studies, Tokyo. The statistic can be found in Kurasawa, Nihon senryōka no Jawa nōson no henyō, p. 232, as well as in Satō, War, Nationalism and Peasants, p. I 59. Miyamoto Shizuo, staff officer of the i6th Army on Java, mentioned the same number: 22, I00 rōmusha were sent from Java to Malaya in I944. Shizuo Miyamoto, Jawa shüsen shoriki [Records at the End of the War in Java] (Tokyo, I973), p. $4 \mathrm{I}$. 
Table I. Transport of rōmusha from Java to other Japanese-occupied territories (1944).

\begin{tabular}{lr}
\hline Destination & Number \\
\hline Malaya & 22,100 \\
Sumatra & 92,700 \\
Northern Borneo & 17,000 \\
(Lesser) Sunda Islands ${ }^{17}$ & 6,000 \\
Sulawesi (formerly known as Celebes) & 20,000 \\
Reserve & 7,200 \\
Subtotal & 165,000 \\
Territories occupied and administered by the Japanese navy ${ }^{18}$ & 63,000 \\
Total & 228,000 \\
\hline
\end{tabular}

Source: Miyamoto, Jawa shūsen shoriki, p. 4I. ${ }^{\text {I9 }}$

used for construction work on the Burma-Siam Railway. All organizations, from local labour bureaus and village headmen (called pengbulu in Malay) to commercial companies, were called upon to provide fixed quotas of labourers. ${ }^{20}$ To meet the first labour force requirements, the Singapore Rubber Association (Shōnan Gomu Kumiai), which controlled the rubber industry on the whole Malay Peninsula, sent 8,000 of their labourers from Perak province alone. The Indian Independence League and the Overseas Chinese Association, likewise coerced into cooperating with the Japanese authorities, sent numbers of romusha in July and August 1943 and again in spring $1944 .{ }^{21}$

At the beginning of recruitment for construction of the BurmaSiam Railway some people even volunteered to work. The Japanese promise of comparatively good pay for a work period limited to between

I7. In the original text, Miyamoto wrote "Sunda Islands", which means the Lesser Sunda Islands (from Bali to Timor), east of Java, which the Japanese called Sunda.

I8. Sulawesi, Southern Borneo (formerly Dutch Borneo), the Moluccas, the Lesser Sunda Islands, New Guinea, and Guam were administered by the Japanese navy. Burma, and the Philippines (until becoming independent in 1943) as well as Hong Kong, Northern Borneo, Sumatra, Malaya, and Java were administered by the Japanese army. But there were also some naval bases located in army territory. Harry J. Benda, James K. Irikura, and Koichi Kishi (eds), Japanese Military Administration in Indonesia: Selected Documents (New Haven, CT, 1965), pp. $5,53 \mathrm{f}$.

19. The 7 th Japanese Army (Southern Army) sent rōmusha from Java to the occupied territories. The Southern Army was installed in Singapore in mid-March 1944, meaning that the numbers of recruits mentioned above do not cover the whole of 1944 .

20. Nakahara, "Nihon senryōki eiryōmaraya ni okeru rōmushadōin", p. I8 I; Michiko Nakahara, "Malayan Labor on the Thailand-Burma Railway", in Kratoska, Asian Labor in the Wartime Japanese Empire, pp. 249-264, 256.

21. Paul H. Kratoska, The Japanese Occupation of Malaya: A Social and Economic History (London, I998), p. I 82 f. According to an article published in a Perak newspaper and dated io August 1943, the Overseas Chinese Association of Perak sent more than 700 forced labourers as a "first batch" to Siam. In Kratoska, The Thailand-Burma Railway, p. 3. 
three and six months appeared attractive in the face of continuing unemployment and miserable living conditions in the villages. ${ }^{22}$ The majority of Malaya's lower classes were illiterate, so in rural areas recruitment for the Japanese was done mainly by word of mouth. Village headmen, foremen on plantations, civil servants at labour bureaus, and Japanese soldiers advertised for construction workers to work on the Burma-Siam Railway in Malaya. Consequently, many people applied for rōmusha after hearing about the Japanese recruitment programme either directly or from friends, neighbours, or relatives. ${ }^{23}$

A certain Shinozaki Mamoru, who as chief of the Ministry for Social Affairs (Kōseika) in Singapore gained deep insights into the labour mobilization, reported on the recruitment of labour in Singapore City. After the war, he placed on record that the offer had appeared to be very good at the beginning of the recruitment drive: "When the Siam-Burma railway started, the Railway Regiment also came to ask for Labour. The document requesting recruits, came to me and I studied it carefully. The terms were very good. [...] The salaries offered were very high compared to other labour wages." ${ }^{24}$ Finally, a department of the Ministry of Social Affairs, which had been established specially for the recruitment of rōmusha (Rōdojimukyoku), ${ }^{25}$ was able to send three contingents of 200 men each from Singapore to Siam. These first recruits were mainly unemployed men, who, according to Shinozaki, set out completely unsuspectingly for the north. ${ }^{26}$

When the first deserters from among the labourers returned to their villages and told of the real working conditions on the Burma-Siam Railway, the Japanese military administration in Malaya began to use deception or coercion in the mobilization of new labourers, an approach tolerated or even supported by the Malayan village headmen, the penghulu. Many documents report on local individuals who were suddenly snatched from their everyday life, press-ganged on the street by

22. Abu Talib Ahmad, "The Malay Community and Memory of the Japanese Occupation", in Patricia Lim Pui Huen and Diana Wong (eds), War and Memory in Malaysia and Singapore (Singapore, 200I), pp. 45-89, 68; PRO, WO 203-5823, SEATIC Bulletin No. 246.

23. Nakahara, "Nihon senryōki eiryōmaraya ni okeru rōmushadōin", p. I78f.

24. Mamoru Shinozaki, My Wartime Experiences in Singapore. Interviewed by Lim Yoon Lin (Singapore 1973), p. 6r. Shinozaki, who was interrogated by the Allies after the war, mentioned that wages were thrice as high in comparison with wages generally in Singapore. For that reason, many people volunteered. Compare Kratoska, The Thailand-Burma Railway, p. 73.

25. Mamoru Shinozaki, Shingapōru senryō hiroku. Sensō to sono ningenzō [Secret Documents about the Occupation of Singapore: The War and the Corresponding Ideal Image of Human Beings] (Tokyo, 1976), p. 92. According to Nakahara, the rōmujimukyoku (労務事務局) had been installed in every province of Japanese-occupied Malaya after October 1943. Nakahara, "Nihon senryōki eiryōmaraya ni okeru rōmushadōin”, p. I 80.

26. Shinozaki, My Wartime Experiences in Singapore, p. 6If. 
Japanese soldiers, loaded onto trucks and effectively kidnapped. Coercive recruitments of that kind happened frequently in public places such as street cafes, cinemas, or after Muslim Friday prayers. There are reports of raids on rubber plantations too. ${ }^{27}$ Coercive recruitment of that kind led to social disorder in village communities and within families, as well as disrupting cultivation and causing supply problems in production not only in Malayan rural areas, but also in every Japaneseoccupied South East Asian territory. ${ }^{28}$

A report by Kuji Manabu, governor of the West Coast province in Northern Borneo (Kita Boruneo), which was separately administrated by the Japanese, serves as an example of the kind of problems that occurred. Kuji reported that locals were urged to perform forced labour to improve the infrastructure, working on the expansion of the road network and the construction of airfields, both vital for the supply of food and raw materials. However, the recruitment of forced labour caused problems within village communities, and those problems had to be solved by the Japanese civil administration in Northern Borneo's West Coast province. Taking local circumstances into account, a rotation scheme was established: “[...] Kuji instituted a time-shift system, whereby small detachments were taken from each village in rotation, to work for one week and then allowed to return to the village, until their turn came again. Regard was paid in the allocation of these units to the conditions prevailing in their kampongs [villages], conditions, for example, differing in a farming community from these in a fishing area". ${ }^{29}$

Furthermore, on the Japanese side, conflicts of interest had arisen between the Southern Army and the civilian administration of the occupied territory. During the first recruitment campaign Singapore's labour department, Rōiojiimukyoku, had been unwilling to send young men to the Burma-Siam Railway. Indeed, the Rōdojimukyoku kept them back as labour for the construction of fortifications in Singapore itself. Consequently, the Japanese military protested - and the regiment responsible for the railway construction loudest of all - complaining "Why is Syonan not

27. Ahmad, "The Malay Community", p. 66; Kratoska, The Thailand-Burma Railway, p. I3; Nakahara, "Nihon senryōki eiryōmaraya ni okeru rōmushadōin", p. I 84ff.; Nakahara, "Malayan Labor on the Thailand-Burma Railway", p. 256.

28. Raben, "Indonesian Rōmusha and Coolies under Naval Administration", p. 2 I 2; Satō, War, Nationalism and Peasants, pp. I65, 178 .

29. PRO, WO 203-6317, SEATIC Intelligence Bulletin No. 237, I 5 June I 946 . Kuji Manabu was the governor of Northern Borneo's West Coast province, one of five provinces in this territory, from 20 November 1943 to I June 1945. Its seat of government was in Jesselton (today: Kota Kinabalu). According to Kuji, 3,000 Javanese rōmusha were used in this province for the construction of roads and airfields. In Malaya, a similar system of part-time work was used in the agricultural sector (especially for (forced) plantation workers). Kratoska, Nihon senryōka ni okeru tōnanajia no keizai jōkyō, p. 269. 
cooperating?" ${ }^{\circ}$ The administrative units of all the other Malayan provinces, including Sumatra, which had sent forced labourers to the BurmaSiam Railway, wondered, too, and asked "Why is Syonan not sending? Why only us? This is unfair." ${ }^{1}$ For that reason, the administration of the occupied territory asked Shinozaki in his role as chief of the social ministry in Singapore and the corresponding labour department, Rōōjimukyoku, to meet the labour quota for restoring economic peace: "Send some labour recruits there, even if it is only a small number, never mind. We are in a difficult position." ${ }^{2}$ According to Shinozaki, in the end the homeless and beggars were collected from the streets, piled onto lorries and transported to where forced labour was needed.

At that time there were many vagabonds in the streets, beggars and homeless people, some from Sumatra. There had been requests from the citizens to clean up the streets; these people were very dirty, some with skin diseases. We were thinking how to do this. Some had been picked up and sent to the reformatory home. The police and the district committee decided to pick up these people and put them into the homes where they were cleaned, fed and treated for a few days. After they had recovered, the Labour Office asked them: "Mau pergi Siam kerja?" ("Want to go and work in Siam?"). Some didn't want. Some accepted. So we sent those who agreed to go. ${ }^{33}$

From the contemporary Japanese point of view, that was a clever move at the time. On the one hand, the Ródojimukyoku was able to meet the designated thirteen contingents as the quota for the labour force, and some 3,000 persons were sent from Singapore to the Burma-Siam Railway. ${ }^{34}$ On the other hand, Singapore's streets were "cleaned". The operation may be understood as the Japanese parallel to the Nazi regime's Zigeunerpolitik (gypsy policy), even if the subjects of it were deported not to extermination camps but to forced labour. ${ }^{35}$ However, the forced labour in Japaneseoccupied South East Asia definitely had an eliminatory characteristic, at least on the Burma-Siam Railway. Incidentally, the "cleaned" streets in the South East Asian metropolis did not remain so for very long, for in spring 1945 there were something like 500 beggars living on the streets of Singapore. They were rommusha from Java and their lot was the result of

30. Shinozaki, My Wartime Experiences in Singapore, p. 62. Japanese-occupied Singapore was named Shōnan or Syonan, which means "light of the south".

31. Ibid., p. 63.

32. Ibid.

33. Ibid.

34. Shinozaki reported that he had been requested to send 3,000 forced labourers (recorded as "coolies") from Singapore. Kratoska, The Thailand-Burma Railway, p. $72 \mathrm{f}$.

35. Concerning the NS-Zigeunerpolitik, see Michael Zimmermann (ed.), Zwischen Erziehung und Vernichtung. Zigeunerpolitik und Zigeunerforschung im Europa des 20. Jahrhunderts (Stuttgart, 2007). 
Japan's war economy and policy: “On account of maltreatment, illness or undernourished they had been unable to work and had been dismissed. Some had run away because of the beatings that were administered. [...] the Japanese do not care whether the coolies run away or not. They get enough replacements from Java." ${ }^{36}$

\section{“COLLABORATION" AS AN AVOIDANCE STRATEGY}

A forced labour organization on Sumatra, which has previously received little attention in research, is the subject of an Allied intelligence report. "Palembang Si" (Parenban-shi), the city administration of the city Palembang in south-eastern Sumatra, organized the Badan-Pembantoe-Pemerintah (BPP), ${ }^{37}$ "a corporation of unskilled labourers for local administrative purposes". This organization was something like a recruitment office, based on orders from Palembang's Japanese governor, who asked the village headmen to meet a certain quota per village as a labour force. Of course, there were local differences in the implementation of the recruitment, which was handled arbitrarily on the whole. In particular, the ranks of the BPP were filled with imports of labourers from neighbouring Java. Reading the Allied documents, we clearly see the coercive nature of the labour recruitment. In the area around Palembang, local people could hardly elude recruitment: "If by chance a man who is selected refuses to join, all his possessions are confiscated and he has to leave his home-town, but wherever else he goes to he is caught by the Japanese and compelled to join the BPP. This only counts for small towns, but in the big towns they are told to join the BPP whether they like it or not." ${ }^{8}$ Following the forced recruitment, the BPP labourers received working clothes: a red-striped shirt, a pair of black work trousers, plus two pairs of underpants, and a straw hat. Moreover, the labourers were identified by a badge that showed a green six-pointed star on a white background and the initials BPP. For a three-month period, the BPP labourers had to work for the Japanese in Palembang, the seat of the local government, away from their home towns. The work consisted of manual labour on so-called government projects, such as construction work on public and government buildings, the construction of roads and bridges, and the repair of bunker installations; but they were also forced to work on rubber plantations. While it is true that the forced BPP labourers were paid for their work, they suffered from poor medical treatment and wholly inadequate

36. NIOD, Labour Requirements Migration: Forced Javanese Labour, 25 June 1945.

37. The abbreviation BPP was also translated as "Badan Pendukung Pemerintah (Government Supporting Organization)". The Indonesian term Pendukung is a synonym for Pembantoe or Pembantu (literally "assistant"). Shigeru Satō, "Occupation: Administration and Policies", in Post, The Encyclopedia of Indonesia in the Pacific War, pp. 6I-147, 69.

38. NIOD, Romusha: BPP (Badan-Pembantoe-Pemerintah), 30 April 1945. 
nutrition. In cases of illness, individuals were forced to continue to work, which naturally resulted in a correspondingly high death rate. At the end of the three-month work period, BPP labourers received a certificate exempting them from further recruitment by the occupier for forced labour. ${ }^{39}$

Among the mainly Chinese immigrant local population of the Malayan provinces of Perak and Kedah - where the Japanese occupying forces had been encouraging iron production - an early strategy to avoid similar forced recruitment as romusha instead of BPP was to specialize in the production of iron nails and other building materials. All such products were then sold to the Japanese, who also accepted the braiding of strong ropes as similarly suitable alternative work, which saved the locals from forced recruitment. In addition, anyone who collaborated economically with the occupying power received diverse grants from the Japanese army..$^{\circ}$

A number of documents show that collaboration with the occupying force was a promising avoidance strategy for escaping rōmusha recruitment. After the war, the Dias brothers, Charles and Anthony, born to a Eurasian father and a Chinese mother, testified that they had agreed to spy for the headquarters of the military police (Kenpeitai) for one reason only, that they wished to avoid forced-labour recruitment and deployment to Siam to work on the construction of the Burma-Siam Railway. ${ }^{4 \mathrm{I}}$

Seventy-five per cent of the Indian National Army (INA), which in summer 1945 numbered 16,000 to 20,000 men, were Tamil civilians. A British intelligence report had this to say about the INA: "[...] However it must not be overlooked that many of them [the Tamils] were forced into the INA to avoid being press-ganged into Japanese labour gangs $[\ldots] "{ }^{42}$

During the war, the unemployed in South East Asia were in particular danger of being recruited as romusha, which explains why service in the paramilitary beibo became an attractive alternative. As auxiliary troops, heibo were guaranteed basic needs such as clothes, food, and accommodation, while wages for heiho were twice those of the rommusha, leading many young men on Java to volunteer for the beibo. ${ }^{43}$ According to the Japanese historian

39. Ibid.; Satō, "Occupation", p. 69.

40. Shinozaki, Shingapōru senryō hiroku, p. 92.

4I. PRO, WO 203-5808, SEATIC Intelligence Bulletin No. 2 I I, 6 October 1945.

42. PRO, WO 203-2298, Supplementary Guide to JIFC (Indian) Activities (Malaya), I6 August 1945.

43. Kurasawa, "Nihon senryōka no Jawa nōson no henyō", p. 205; Kaori Maekawa, "Taheiyōsensō ni okeru nihongun no horyoseisaku to ajiakei horyo no gunjidōin - Indoneshia ni okeru heiho seido o chūshin ni" [The Japanese Army's Policy Concerning Prisoners of War during the Pacific War and the Mobilization of Asian Prisoners of War for War Purposes - with special focus on the heibo system in Indonesia] (Ph.D. dissertation, Sophia University Tokyo, 2009), p. 97. 
Maekawa Kaori, in the context of the worsening war situation local administrators, such as village headmen, confronted many such young men with the choice of either becoming romusha or volunteering for the beibo. The occupying power spared no one from the general mobilization, and each family was required to provide at least one individual, ${ }^{44}$ meaning that in many places the young men were forced to choose "the lesser of two evils". ${ }^{45}$

In this context, the destinies of forcibly recruited romusha and members of collaborating paramilitary troops were closely linked. One example is a beibo platoon from Malaya's north-western province Kedah. The beibo was installed on guard duty at the Tamarkan Camp on the Burma-Siam Railway and received orders to shoot disobedient romusha. ${ }^{46}$

In reality, most voluntary recruits of the beibo, who received military training similar to that of Japanese soldiers, ${ }^{47}$ did work resembling that done by the coercively recruited rōmusha, being set to dig ditches, mend roads, or to do agricultural work ${ }^{48}$ So the institution of the beibo, which started on the Malay Peninsula in May 1943, must be understood as another part of the general mobilization of labour in South East Asia. ${ }^{49}$

\section{COERCED LABOUR IN THE INFRASTRUCTURE:}

\section{INTERPRETATIONS IN TERMS OF LABOUR RELATIONS}

Our knowledge of coerced labour during the Japanese occupation of South East Asia is still severely limited because of the general shortage of primary sources and limited access to documents from Japanese commercial companies active in occupied South East Asian territories from 1942 to I945. It is therefore very difficult to formulate any comprehensive definition of

44. Maekawa, "Taheiyōsensō ni okeru nihongun no horyoseisaku to ajiakei horyo no gunjidōin”, p. 99.

45. Joyce C. Lebra, Japanese-Trained Armies in Southeast Asia: Independence and Volunteer Forces in World War II (Hong Kong, 1977), p. i i ff.

46. Ahmad, "The Malay Community", p. 7I. According to documents of the I6th Japanese Army (Java), the majority of the heiho did service as guards. Waseda daigaku ajia taiheiyō kenkyū sentā [The Asia-Pacific Research Institute of the Waseda University in Tokyo], Nishijima Collection, JV 45, The Headquarters of the i6th Army. Explanations Regarding All Kinds of Armed Bodies, I945.

47. Waseda daigaku ajia taiheiyō kenkyū sentā.

48. Ban Kah Choon and Yap Hong Kuan, Rehearsal for War: Resistance and the Underground War against the Japanese and the Kempeitai, 1942-1945 (Singapore, 2002), p. 68; Joyce C. Lebra, "The Significance of the Japanese Military Model for Southeast Asia”, Pacific Affairs, 48:2 (1975), pp. 2 I 5-229, 223; Geok Boi Lee, The Syonan Years: Singapore under Japanese Rule 1942-1945 (Singapore, 2005), p. 255.

49. Only a few publications about the beibo mobilization are in Western languages. For an introduction to the subject see Kaori Maekawa, "The Heiho during the Japanese Occupation of Indonesia", in Kratoska, Asian Labor in the Wartime Japanese Empire, pp. 179-196. 
"coerced labour during the Japanese occupation in South East Asia" in terms of labour relations. The spectrum of forced labour was most likely wide-ranging - for example from manual to non-manual work, or from those who worked for the occupying power to those who worked for private Japanese employers. Many more case studies are required to allow us a usefully closer view of the subject. That said, a first attempt at an interpretation of romusha labour relations might read as follows. It is based on what is known so far about the forced recruitment of local inhabitants for manual work conducted "in the name of the state", meaning, of course, Japan, as the occupying power.

With reference to the construction of the Burma-Siam Railway, it becomes obvious that, initially, the Japanese meant to recruit volunteers as manual labourers, but that soon after the recruitment process had started it became clear to them that too few of the local inhabitants were prepared to volunteer to do that type of work. The Japanese were therefore obliged to adopt other methods to acquire a large enough workforce, and the recruitment of locals by force increased. The taxonomy of the romusha's labour relation is in accordance with the development of the recruitment process, in that generally speaking the romusha of the Burma-Siam Railway and most other construction projects worked for the polity, under a new system that was propagated with the catchphrase "Greater East Asia" (Daitōa). Those rōmusha were tributary labourers and their labour was not commodified. Upon closer examination, however, we can see clearly that the first labourers working on the Burma-Siam Railway were, in principle, wage labourers for the polity (labour relation I 8) and at least some of them were able to return home. Once home, the returnees reported on the real working conditions along the railway, which unsurprisingly had a dramatic impact on the recruitment process. From then on - and with good reason - almost no one volunteered and so the occupying power saw no option but to intensify its coercive recruiting. In conclusion, local inhabitants recruited by force to work as rōmusha, for example on the Burma-Siam Railway, which was the greatest construction project of the Japanese occupation period in South East Asia, may be described generally - and in reference to the categories of labour relations defined by Karin Hofmeester et al. - as "tributary slaves" (labour relation I I). The rōmusha of the "Death Railway" were owned by and worked indefinitely for the polity; they were deprived of the right to leave the railway and could not return home. Many died along the railway either as a consequence of the cruel working conditions or in attempts to escape to their homes. ${ }^{50}$

50. Karin Hofmeester et al., "The Global Collaboratory on the History of Labour Relations, I 500-2000: Background, Set-Up, Taxonomy, and Applications", available at http://hdl.handle. net/ro622/4OGRAD, last accessed 25 April 2016. 


\section{CONTINUITY OF LABOUR RELATIONS IN PRE-WAR AND WARTIME SOUTH EAST ASIA}

The Japanese were the last major group to enter the labour market of South East Asia at the end of the nineteenth century. At the beginning of the twentieth century, thousands of Japanese immigrants worked not as colonial entrepreneurs, but also as "coolies", for instance on the construction of the Baguio road in the Philippines. But after its opening up to the West from the mid-nineteenth century, the Japanese empire modernized and industrialized rapidly and Japan's economy grew. The result was that the Japanese empire's role in Asia shifted in economic terms. The islands of Japan itself, which had so far exported mainly cheap labour to neighbouring countries, were now increasingly represented in South East Asia by mercantile people. However, in comparison with the period of Japan's occupation of South East Asia its prior economic involvement had been marginal. During the first half of the twentieth century, Japanese manufacturers primarily exported their own products, for example textiles, and Japanese companies acted as importers of local raw materials. ${ }^{5 \mathrm{I}}$

Until the beginning of the I940s, the natural resources of South East Asia (raw materials, but mainly also oil for petroleum products) were in increasingly high demand in Japan, until, in the end, demand for those natural resources became one of the main reasons for Japan's decision to occupy the South East Asian territories. But Japan's mobilization of labour changed as the war went on. Immediately after the seizure of the Asian territories the new occupying power began to mobilize labourers for restoration work, such as the reconstruction of bridges, harbour facilities, or strategically important factories. That phase of restoration continued until around autumn 1943, but from the second half of I943 the likely course of the war, with its inevitable consequences, became increasingly impossible to ignore. Japan could obviously expect an Allied invasion of South East Asian territories, so labourers were mobilized for defence projects such as the construction of military airbases or fortifications. In addition to "defence", "production" now became a key word in Japanese propaganda. As a consequence of the Battle of Midway and its subsequent mounting loss of maritime control, which had brought with it the pervasive shortage of food, clothing, and other daily necessities, from summer 1943 onwards Japan began a campaign to increase local self-sufficiency, especially in food, in all areas under the direct control of its empire, such as the territories of the former Dutch East Indies, Malaya, and the Philippines. Pure pragmatism had by now replaced the original Japanese idea of establishing a "Greater East Asia Co-Prosperity Sphere" with Japan at its centre. 
The extensive mobilization of the workforce, and especially the so-called Grow More Food Campaign, was a "total mobilization" not only of skilled, but also of unskilled workers. Simply put, it was nothing less than the mobilization of the entire society of South East Asia, owing to pragmatic reasons in wartime. "The Japanese conducted a series of campaigns for a 'total mobilization' of manpower under the slogan of 'defence and production.' These campaigns involved virtually the entire workforce in the occupied land, including many women and children." 52 "Production" referred to, among other things, strategic resources such as oil, minerals, or ammunition, clothing both for the troops and local inhabitants, as well as construction work for the transport sector. Food production, especially of staples such as rice became much more important on the plantations than the production of export crops, which had lost their markets anyway because of Japan's economic isolation. One consequence was, therefore, the continuous deterioration of the plantation economy during the Japanese occupation. ${ }^{53}$ It is worth pointing out that, in the context of total labour mobilization, the experiences of the people mobilized varied greatly, but the fate of indigenous forced labourers was the most extreme of course. ${ }^{54}$

However, it was not the Japanese occupying power that was the first to introduce coercive labour into South East Asia as a mode of production, for the preceding Western colonial governments had used state power to draft corvée labour or to force the inhabitants to grow food for local consumption. For example, in Java as early as the mid-nineteenth century local peasants had been forced by the colonial power to produce food, while in I 830 the colonial government of the Dutch East Indies established a cultivation system under which the local peasants had to provide clearly determined quantities of foodstuffs to the government. Sugar as well as coffee became typical Javanese products, the export of which was based on a modern tribute system. Even if that cultivation system had been abolished by about $\mathrm{I} 870$, nevertheless "[...] the Javanese were no longer compelled to work by the state, $[\ldots]$ in practice most of them kept growing the same crops under very similar conditions. By the late nineteenth century the use of direct coercion in export production was generally disappearing in South East Asia, less because it violated principles of human rights and dignity than because it was inefficient." 55

52. Satō, "Relocation of Labor", p. 245 .

53. Aiko Kurasawa, "Social Change", in Post, The Encyclopedia of Indonesia in the Pacific War, pp. 282-289, 289 .

54. Satō, "Relocation of Labor", p. $248 f$.

55. Owen, The Emergence of Modern Southeast Asia, p. I $80 f f$. See also Elise Nederveen van Meerkerk's contribution to the present Special Issue, "Grammar of Difference? The Dutch Colonial State, Labour Policies, and Social Norms on Work and Gender, c. I800-1940". Concerning the quote, see Owen, The Emergence of Modern Southeast Asia, p. I 82. 
By the beginning of the twentieth century the industrial revolution had entered a new stage. Among other things, the motor industry was developing at a great pace, which led to increasing demand worldwide for oil and rubber. Until the outbreak of World War II, more than ninety per cent of the world's rubber came from South East Asia, and the Dutch East Indies and Malaya were teeming with rubber plantations, where the "[working] conditions were terrible [...], with long hours, poor food, inadequate medicine, and strict discipline leading to high desertion and mortality rates." ${ }^{56}$ At the outbreak of the war, South East Asia as a workplace was dominated by a plantation economy with harsh working conditions.

In conclusion, Japanese administrators found themselves able to use the harsh working conditions of earlier colonial systems as a springboard for their own approach. Under Japanese rule, forced labour therefore experienced a renewal, although to a much greater extent and under much harsher conditions. Japan was at war, so this was a war economy, and the unfavourable course of the war for Japan served as a catalyst for the exploitation of the indigenous people as forced labourers.

Even the transport and relocation of labourers was not unique to the Japanese occupation period. The system of plantations, which prevailed in the period of the early industrialization of South East Asia, had always been based on the import of human labour. Plantations (rubber, tea, coffee, tobacco, palm oil, etc.) were in general established in "empty" regions where suitable land was both cheap and abundant and the population was comparatively sparse, such as in areas of Sumatra or Malaya. Because

$[\ldots .$.$] the locals had no need or desire for wage labor - their eventual response to the$ rubber boom [in the first half of the twentieth century] was smallholding rather than working on the estates - so plantation managers imported immigrant labor to work the fields. [...] Over time many immigrant workers settled in, local peasants began to change their economic outlook and accept wage labor $[\ldots] .^{57}$

When the Chinese, as the first "batch" of imported labourers, began increasingly to work as tradesmen or shop owners in the cities, from about I 890, the Javanese became the main source of imported labour on plantations in South East Asia. ${ }^{58}$ Of course, the main difference from the time of the Japanese occupation came from below. At the turn of the century, the need for plantation workers attracted migration into South East Asia, and immigrants themselves took the initiative in their own movement.

56. Owen, The Emergence of Modern Southeast Asia, p. I 84.

57. Ibid., p. I83. Even "in sparsely populated Malaya, much of the labour the plantations needed came from Indian and Chinese immigrants". Nicholas Tarling, Southeast Asia: A Modern History (South Melbourne and Oxford, 200r), p. I92.

58. Owen, The Emergence of Modern Southeast Asia, p. I 86. 
By contrast, during World War II it was the Japanese occupying power acting from above that forced Javanese or Malayans to leave their homes and go to work as labourers in other parts of the "Greater East Asia Co-Prosperity Sphere”.

Although the war economy in Japanese-occupied South East Asia is a comparatively under-researched topic, it is well known that, in general, the economies of the occupied territories, for example that of the former Dutch East Indies, deteriorated during the war. Living conditions became worse for many reasons, such as disorderly production, inflation, and corruption. ${ }^{59}$ Before the war, most South East Asian territories were fully integrated into the world economy and some, such as the Malay Peninsula with its rubber production, were economically significant. However, labour relations were greatly affected when production decreased at the beginning of the occupation for the simple reason that Japan and its occupied zones were cut off from the world market. Unemployment, especially in urban areas, was one consequence during the initial stage of the occupation, although joblessness and general destitution had already become serious problems before the war. For example, during the first half of the twentieth century, many thousands of inhabitants worked full time or seasonally on Java's plantations, producing crops such as tea, coffee, rubber, or sugar for export. Because of the worldwide economic crisis and because of the outbreak of World War II in Europe in 1939, the production and export of crops in Java were drastically reduced, causing large-scale unemployment that, in turn, led to begging and prostitution..$^{60}$

Many historically interesting sources from the occupation period were systemically destroyed, among them information on the "recruiting" of rōmusha, while some of those that survived the war are inaccessible for various reasons. Thus, it is rather difficult to answer the question of exactly what kind of work people did before their recruitment as rōmusha. Concerning Java at least, it is known that in the I930s most people worked in the agrarian sector as peasant smallholders or on the plantations and in the import-export market. At the outbreak of World War II in Europe, the Indonesian territories lost their export markets - with the exception of that for rubber, which was now in great demand in the United States. Nevertheless, a great many plantation workers were dismissed and no-income areas like the northern territories of Java became real hunger zones. Although Japan tried to replace the European factories with Japanese ones, Java's industry collapsed during the war years from lack of resources and transport problems. Not much data is available about the employment

59. Shigeru Satō, "Introduction", in Post, The Encyclopedia of Indonesia in the Pacific War, p. 218.

60. Satō, "Relocation of Labor", p. 250. 
situation immediately before Japan invaded Java, but according to the Japanese historian Satō Shigeru, "a regional difference was observed between the western half and eastern half of the island [Java]. [...] unemployment and destitution became markedly more serious in the eastern half". ${ }^{11}$ On the one hand, local inhabitants who had already lost or were losing their work on plantations or in cities returned to the rural areas. On the other, those who had lost their livelihoods in the countryside migrated to urban areas. In the cities of, in particular, eastern Java, more beggars and prostitutes were noted, ${ }^{62}$ a tendency, already visible at the end of the Dutch era, now intensified by the nascent international economic isolation of the Japanese-occupied South East Asian territories and which caused workers in export-import industries, for example, or military personnel of the former colonial forces to lose their jobs too. Japan as the "new power" was unable to generate enough jobs for those newly unemployed. It is notable that the development of the employment situation on the Malay Peninsula and in Singapore seems to bear a resemblance to that in Indonesia. As a result, the Japanese were able to draw on a large pool of the unemployed when it began to draft rōmusha from spring 1943 onwards. As Satō says, "The Japanese inherited Dutch policies in broad outlines but the manner in which they enforced the policies, such as [...] forced mobilization of labour, were obviously inappropriate and worsened the economic conditions." ${ }^{3}$

While at the beginning of the Japanese occupation the mass of the unemployed, especially from export industries, increased because of Japan's worldwide economic isolation, by the end of the occupation there were actually shortages of labour in places after the Japanese had mobilized and transported local inhabitants as forced labourers. Concerning this phenomenon Satō states:

If the Japanese had needed labor solely for their military operations, this surplus population would have been more than enough, and Java would have continued to suffer from serious unemployment throughout the occupation. The mobilization campaigns from late 1943 soon eradicated unemployment, however, and created labor shortages in many villages from around mid-I944. The labor mobilization for the Japanese defense endeavor was substantial, but their economic endeavors also absorbed much labor. The transformation from a surplus to a shortage of labor can be explained to an extent in terms of a decline in production efficiency in an isolated economy. ${ }^{64}$

61. Shigeru Satō, "Indonesia 1939-1942: Prelude to the Japanese Occupation", Journal of Southeast Asian Studies, 37:2 (2006), pp. 225-248, 242.

62. Ibid.

63. Ibid., p. 248.

64. Satō, "Relocation of Labor", p. 247. Concerning the inefficiency of production, Satō gives the example of coal mining in Java. The Japanese authorities tried to recommence the import of coal, but it was impossible because of the lack of cargo ships. The main body of these ships (before the war around seventy per cent of them were British or Dutch) had left the area prior to the Japanese 
However, unemployment in Japanese-occupied South East Asia had its roots in pre-war times, and its development was clearly continuous. Not only in Java, but in other occupied territories, too, Japan encountered a system of labour relations that was already unstable and suffering from the prevailing economic crisis and the consequences of the outbreak of the war in Europe.

Finally, with regard to Java, one parallel between the pre-war Dutch and the Japanese economic systems is striking. Neither the Dutch colonial authorities, nor the Japanese administrators were really interested in industrializing Java. Because of the worldwide depression and the outbreak of World War II in Europe, the Dutch were, on the one hand, more or less forced to introduce basic industries such as metal, chemical, textile, or paper industries in its colony. But in reality, even the Dutch had hitherto considered Java as a source of resources, meaning raw materials, export crops, and cheap labour. For Japan, it was the course of the Pacific War that forced the imperialist state to change its initial plan of building an "Asian economic bloc" and establishing a system of economic "self-sufficiency" in South East Asia. Consequently, in certain fields industrial efforts had to be intensified. ${ }^{65}$ In fact, the real industrialization of the region began only after the war, when a process of recovery and economic modernization accompanied the return of the pre-war colonial powers to their former South East Asian territories. In the end, the targeted restoration of pre-war political and economic patterns was partly successful. Finally, with the liberation movements, the shaking off of the yoke of colonial rule, and the founding of independent nation states, forced labour disappeared from South East Asia.

\section{CONCLUSION}

Japanese historians such as Kurasawa Aiko, Gotō Kenichi, and Satō Shigeru are pioneers of research on rōmusha. Nevertheless, they have focused largely exclusively on Indonesia and in particular on Java, because Java was Japan's main source of forced labourers in South East Asia. Javanese rōmusha were shipped from Java, mostly via Sumatra, to neighbouring regions, or used on the spot, including, notoriously, as forced labourers on the Burma-Siam Railway. The majority of the labourers on the "Death Railway" were not, in fact, the Allied POWs, but people from Burma or Malaya. It should also not be forgotten that the romusha of the Burma-Siam Railway project were themselves not the only forced labourers in the

invasion. The Japanese authorities were therefore forced to begin coal mining, mainly in the western part of Java. But even if labour was mobilized for the mining and for the construction of a railroad to transport the coal on the island, the effect was minimal and the coal shortage increased, although there was an enormous amount of coal on the neighbouring islands.

65. Ibid., p. 253 . 
"Greater East Asia Co-Prosperity Sphere". Forced labour was used in various sectors, but not all of it was manual labour. Besides, the conditions of forced labourers could differ considerably, even on the Burma-Siam Railway.

Indeed, the prospect of recruitment for the construction work on the Burma-Siam Railway was without doubt greatly feared by all of Malaya's local populations, their fear prompted chiefly by the reports of returnees about the appalling working conditions on the "Death Railway". Ironically, many of those returnees had volunteered to work on the railway, but fled when they realized the truth of the situation in Siam.

At the same time as the Japanese increasingly used force to recruit labour, the local population found ways to develop avoidance strategies. For example, to escape romusha, some locals took to specializing in the production of certain goods necessary for the Japanese troops in the region. Others collaborated with the occupying force in other ways, such as the young men who were confronted with the choice of being frogmarched into a batch of romusha or volunteering to join paramilitary outfits like the beibo. Some locals did construction work other than that on the BurmaSiam Railway, perhaps working on other railway projects, or building airfields and other kinds of construction works. They were, in turn, guarded and overseen by other locals who had joined a collaborating paramilitary unit, an aspect of romusha that is only one "irony of the history" of the Japanese occupation of South East Asia. Further, it illustrates an unintended consequence of the actions of the occupying power, whose aim had been to recruit labour for the Burma-Siam Railway, by coercion, if necessary. Yet, the ultimate effect was that members of the labour force chose less coercive labour relations, and even if their agency led them into collaboration rather than open resistance, the imposition of particular labour relations could sometimes be eluded. 